\title{
Morphological changes of the mucous membrane in children with chronic gastroduodenal pathology and infection with cytotoxic strains of Helicobacter pylori \\ Zmiany morfologiczne błony śluzowej u dzieci z przewlekłą chorobą żołądka i dwunastnicy oraz zakażeniem cytotoksycznymi szczepami bakterii Helicobacter pylori
}

Department of Paediatrics, Vinnytsia Pyrohov Memorial National Medical University, Vinnytsia, Ukraine

Correspondence: Kateryna Khromykh, 15 Saksaganskogo str., apt. 58, Vinnytsia, Ukraine, 21032, tel.: +380634009099, e-mail: kate_khromykh@yahoo.com

\begin{abstract}
Introduction: Helicobacter pylori plays the main role in the development of chronic pathology of the gastroduodenal area. Helicobacter pylori infects $25 \%$ of the population in developed countries and up to $90 \%$ in developing countries. The most virulent are CagA positive (+) strains of Helicobacter pylori, which cause an intense cellular response, i.e. inflammation of the stomach mucous membrane, cell proliferation and cell death. Material and methods: We examined 75 children, aged 10 to 18 years, with chronic gastroduodenal pathology associated with Helicobacter pylori. A morphological and morphometric study of the stomach mucous membrane was performed depending on the presence of cytotoxic strains of Helicobacter pylori. Results: In children infected with CagA (+) strains of Helicobacter pylori, active and deep chronic gastritis and gastroduodenitis [21 (28.00\%), 20 (26.67\%), respectively] were more common than in children with CagA (-) strains [10 (13.33\%), 13 (17.33\%), respectively]. Discussion: Morphological studies provide an opportunity to determine quantitative and qualitative changes in the mucous membrane of the stomach in gastroduodenal pathology associated with Helicobacter infection. This increases the quality of diagnosis and predicts the course of the disease. Conclusion: A morphological study has shown that the presence of cytotoxic strains of Helicobacter pylori contributes to more significant changes in the gastric mucosa in children with chronic gastroduodenal pathology.
\end{abstract}

Keywords: children, Helicobacter pylori, chronic gastritis, gastroduodenitis, mucous membrane of the stomach

Streszczenie Wstęp: Helicobacter pylori odgrywa główną rolę w rozwoju przewlekłej choroby żołądka i dwunastnicy. Zakażenie tą bakterią dotyczy 25\% populacji w krajach rozwiniętych i około $90 \%$ w krajach rozwijających się. Najbardziej wirulentne szczepy CagA-pozytywne (+) powodują intensywną odpowiedź komórkową w postaci stanu zapalnego błony śluzowej żołądka, proliferacji komórek i apoptozy. Materiał i metody: Badaniem objęto 75 dzieci w wielu 10-18 lat z przewlekłą chorobą żołądka i dwunastnicy związaną z zakażeniem Helicobacter pylori. Ocenę morfologiczną i morfometryczną błony śluzowej żołądka przeprowadzono w zależności od obecności cytotoksycznych szczepów Helicobacter pylori. Wyniki: W grupie dzieci zakażonych szczepami CagA (+) postać aktywna i głęboka zapalenia żołądka i dwunastnicy [odpowiednio $21(28,00 \%)$ i 20 (26,67\%)] występowała częściej niż w grupie dzieci zakażonych szczepami CagA (-) [odpowiednio 10 (13,33\%) i $13(17,33 \%)$ ]. Omówienie: Badania morfologiczne umożliwiają ocenę ilościową i jakościową zmian w błonie śluzowej żołądka u pacjentów z chorobą żołądka i dwunastnicy związaną z zakażeniem Helicobacter pylori. Zwiększają tym samym jakość diagnostyki i pozwalają przewidzieć przebieg choroby. Wnioski: Badanie morfologiczne wykazało, że zakażenie cytotoksycznymi szczepami bakterii Helicobacter pylori przyczynia się do powstawania istotnych zmian w błonie śluzowej żołądka u dzieci z chorobą żołądka i dwunastnicy.

Słowa kluczowe: dzieci, Helicobacter pylori, przewlekłe zapalenie żołądka, zapalenie żołądka i dwunastnicy, błona śluzowa żołądka 


\section{INTRODUCTION}

$\mathrm{P}$ athologies of the digestive system, namely chronic gastritis and gastroduodenitis, occupy one of the leading places among diseases in children. Their prevalence is $58-78 \%$. Helicobacter pylori plays the main role in the development of chronic gastroduodenal pathology. According to studies of the World Gastroenterology Organisation, the prevalence of Helicobacter pylori infection is $4-25 \%$ in countries with high socioeconomic status, while in developing countries, it reaches up to $90 \%$ or more ${ }^{(1,2)}$.

Helicobacter pylori infection is an important pathogenetic link in the development of the gastroduodenal pathology. Helicobacter pylori causes duodenal ulcers in $90-95 \%$ of cases and stomach ulcers in $60-80 \%$ of cases $^{(3)}$.

The main pathogenetic factors of Helicobacter pylori involve the colonisation of the gastric mucosal bacteria, adhesion to the gastric epithelium, intracellular penetration, cytotoxins, pathogenicity islets, specific reactions to stress, and the human immune response to infection.

Currently, it is known that genomes of Helicobacter pylori contain genes, including vacA, ice A, cagA and abA, associated with an increased pathogenicity of the microorganism. The most virulent Cag positive (+) strains of Helicobacter pylori are thought to cause an intense cellular response: inflammation of the gastric and duodenal mucosa, cell proliferation and cell death ${ }^{(4-6)}$.

Chronic gastritis and gastroduodenitis is a clinical and morphological diagnosis; therefore, the diagnostic "gold standard" should be a morphological examination of the mucous membrane of the stomach, which makes it possible to determine the depth and nature of the lesion ${ }^{(7)}$. Despite significant advances in the study of gastroduodenal pathology in children, there are a number of problems related to investigations of morphological changes in the gastric mucosa in various forms of gastritis and gastroduodenitis, and to cytotoxic strains of Helicobacter pylori.

\section{AIM OF THE STUDY}

The aim of the work was to study morphological changes of the gastric mucosa in children with chronic gastroduodenal pathology, depending on the presence of Helicobacter pylori and its cytotoxic strains.

\section{MATERIAL AND METHODS}

During the course of our work, we examined 75 children, aged 10 to 18 years, with chronic gastroduodenal pathology, treated at the Paediatric Department Number 2 of the Vinnytsia Regional Children's Clinical Hospital. The study was conducted in compliance with the main provisions of the GCP (1996) of the Council of Europe Convention on Human Rights and Biomedicine (dated 04.04.1997) of the Helsinki Declaration of the World Medical Association on the Ethical Principles of Human Medical Scientific Research (1964-2000).

The examined children were divided into two groups depending on the cytotoxicity of Helicobacter pylori strains. The first group included 38 children (50.6\%) who were infected with CagA (+) strains, and the second group contained 37 patients $(49.3 \%)$ infected with Cag (-) strains of Helicobacter pylori. The control group consisted of 10 children with chronic gastritis and gastroduodenitis without Helicobacter pylori infection.

A general investigation performed for all patients involved collection of complaints, anamnesis, an overall clinical picture and laboratory and instrumental studies. Endoscopic examination of the upper gastrointestinal tract was carried out by using the OLYMPUS GIF-XPE apparatus with an intragastric $\mathrm{pH}$ meter. The presence of Helicobacter pylori was determined by a rapid urease test (URE-HP test). The presence of the cytotoxic CagA $(+)$ strain of Helicobacter pylori was determined with an ELISA enzyme assay kit. At endoscopic examination, patients underwent a biopsy of the gastric mucosa with a subsequent morphological examination. For a morphological study, the biopsy material was fixed in a neutral $10 \%$ formalin solution. The next step after fixation was dehydration in alcohol of an increasing concentration, the purpose of which was to prepare tissues for pouring into paraffin. Micrometal sections were stained with haematoxylin-eosin using the van Gieson method. The obtained histological preparations were studied by microscope (Uranum) in a $100 \times$ and $200 \times$ magnification. In the stomach biopsy, the following were evaluated: the relative volume of epithelial cells, the height of epithelial cells, the diameter of epithelial cells, the relative volume of the affected epithelial cells, the relative volume of capillaries, erythrocyte sedimentation rate of capillary blood, the relative volume of glandular structures, and cell density of the infiltrate. In addition, the following were determined: the total area of the biopsy, the total number of cellular elements in the inflammatory infiltrate, the number of plasma cells, the number of lymphocytes, and the presence of intestinal metaplasia in the coat - jaw epithelium.

\section{RESULTS}

The morphological analysis in children with chronic gastritis and gastroduodenitis showed that the superficial and inactive inflammatory process in the gastric mucosa predominated [44 (58.67\%), 42 (56.00\%), respectively], whereas deep and active changes were diagnosed in $33(44.00 \%)$ and 31 patients $(41.33 \%)$, respectively. Flexural metaplasia of the cervical mucosal epithelium of the stomach was noted in 58 patients $(77.33 \%)$, of which 34 (58.62\%) were infected with CagA (+) strains of Helicobacter pylori.

There was a difference in the histological picture between infected and not infected children. Inflammatory changes, manifested by diffuse lymphoplasmic infiltrates 


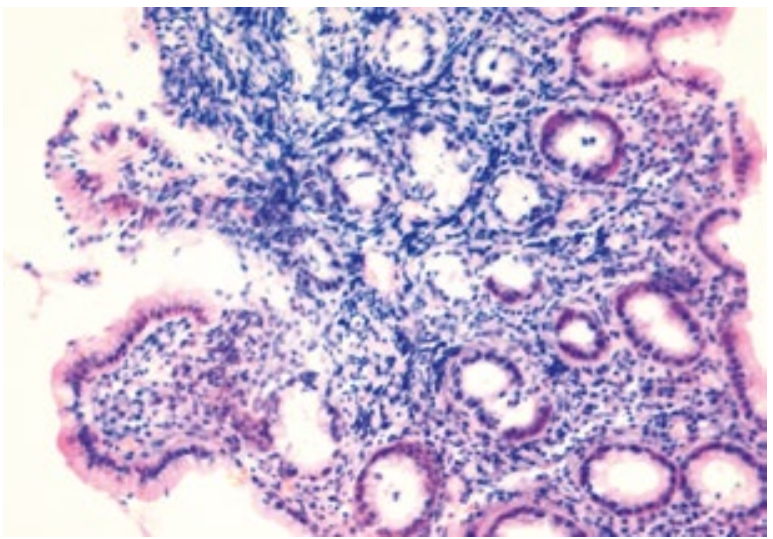

Fig. 1. Chronic non-atrophic deep inactive gastritis in a 13-yearold patient (K.). Haematoxylin-eosin staining. Magnification: $\times 200$

with a predominance of lymphocytes in their own plate (Fig. 1), prevailed in children with chronic gastritis without Helicobacter pylori infection.

Children with chronic gastritis and gastroduodenitis associated with Helicobacter pylori infection presented with more pronounced changes in the gastric mucosa. Thin-cell metaplasia of the epithelium with focal fibrosis of its plate and lymphoplasmic inflammatory infiltrates, focal desquamation and dystrophy of the glandular epithelium, and the presence of lymphoid follicles indicates Helicobacter pylori the associated nature of inflammation (Fig. 2).

In the morphological study of the gastric mucosa depending on the presence of cytotoxic strains, it was found that CagA (+) strains of Helicobacter pylori accompany changes that are more significant. In children infected with CagA (+) Helicobacter pylori strains, active and deep chronic gastritis and gastroduodenitis were more common [21 (28.00\%), 20 (26.67\%), respectively] than in those with CagA (-) Helicobacter pylori strains [10 (13.33\%), $13(17.33 \%)$, respectively].

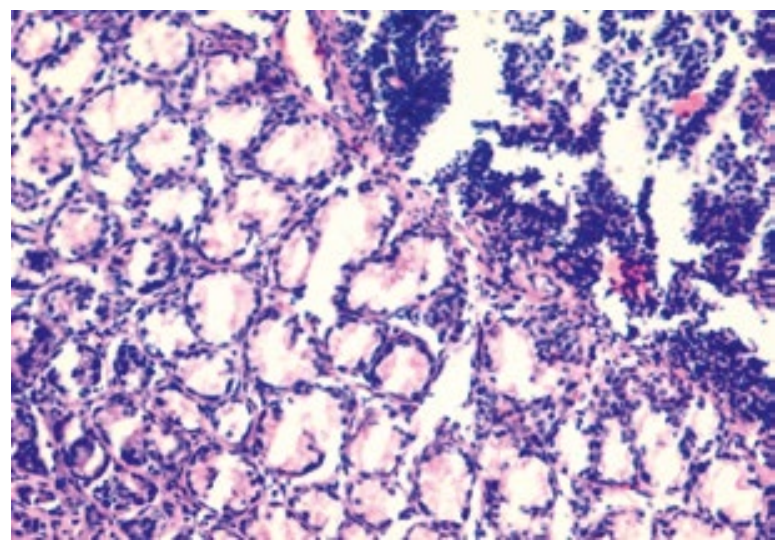

Fig. 2. Chronic non-atrophic moderate inactive gastritis with the presence of lymphoid follicles and focal thromboembolic metaplasia of the epithelium in a 13-year old patient

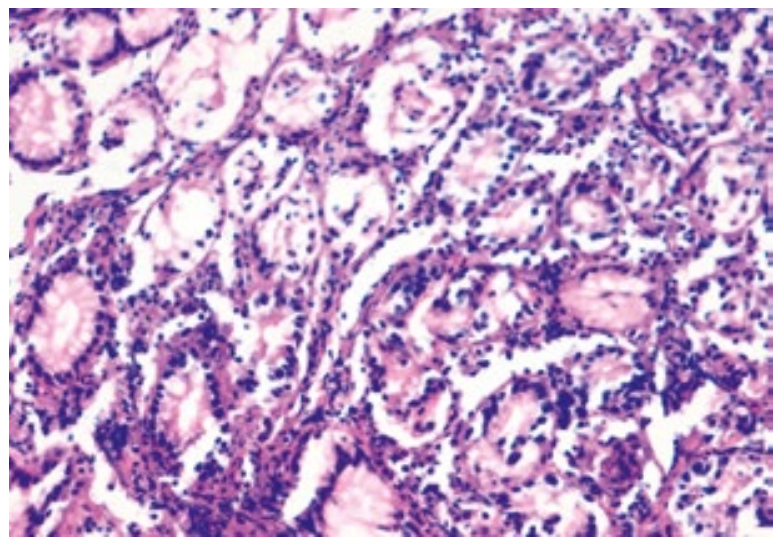

Fig. 3. Chronic non-atrophic deep gastritis with lesions of the glands, grade I activity with focal, small-cell metaplasia of the epithelium and the presence of lymphoid follicles in a 14-year-old patient (G.). Haematoxylin-eosin staining. Magnification: $\times 200$

Intestinal metaplasia of the gastric mucosa was detected in 58 children $(77.33 \%)$ with chronic gastritis and gastroduodenitis, of which 34 (58.62\%) were infected with CagA (+) strains of Helicobacter pylori. Apart from small-cell lung and metastatic lymphoplasmosis, haemorrhages were observed in 5 children (6.67\%) infected with CagA (+) Helicobacter pylori strains, which may be indicative of severe damage and increased rapture of the vascular walls. Also, a single biopsy of the gastric mucosa revealed the presence of diffuse lymphoplasmocytic infiltration of the own plate and lymphoid follicles combined with subcutaneous metaplasia of the periosteal and pharyngeal epithelium (Fig. 3).

In children with chronic gastritis and gastroduodenitis associated with CagA (-) strains of Helicobacter pylori, histological changes in the gastric mucosa were less pronounced: inactive inflammatory process in 27 patients $(36.00 \%)$ and superficial changes in 23 patients (30.67\%). Morphological changes in the mucous membrane of the stomach were manifested by moderate lymphoplasmocytic infiltration of the own plate with the presence of lymphoid follicles with

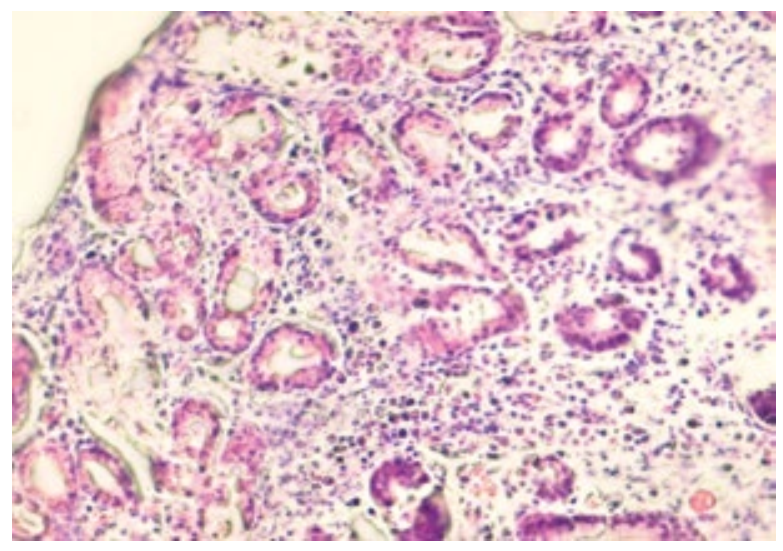

Fig. 4. Chronic non-atrophic deep inactive gastritis with focal, small-cell metaplasia of the epithelium and the presence of lymphoid follicles in a 12-year-old patient (S.). Haematoxylin-eosin staining. Magnification: $\times 200$ 
small centres of lymphocyte proliferation and focal thromboembolic metaplasia (Fig. 4).

For a complete assessment of histological changes in the gastric mucosa in children with chronic gastritis and gastroduodenitis, a morphometric study of the biopsy was performed, which showed a difference depending on the presence of cytotoxic strains of Helicobacter pylori. In children with chronic gastritis and gastroduodenitis infected with CagA (+) strains, the total number of inflammatory cells (plasmocytes, lymphocytes) doubled (50.84 \pm 2.13 ) compared to the equivalent indicator in children infected with CagA (-) strains of Helicobacter pylori $(25.03 \pm 0.71)$. The difference was statistically significant $(p<0.05)$. The study found that in the gastric mucosa of children with chronic gastritis and gastroduodenitis associated with CagA (+) strains of Helicobacter pylori, there was a significant $(p<0.05)$ increase in the number of plasmocytes $(37.47 \pm 1.98)$ and lymphocytes $(10.61 \pm 0.47)$ compared with patients infected with CagA (-) strains (18.81 \pm 0.50 and $5.35 \pm 1.99$, respectively) (Tab. 1).

Also, the investigation revealed a significant $(p<0.05)$ increase in the relative volume of affected epithelial cells in children infected with CagA $(+)$ Helicobacter pylori strains $(38.03 \pm 0.47 \%)$ compared with children with CagA (-) strains $(30.73 \pm 0.37 \%)$. In addition, it was determined that the height of epithelial cells was significantly $(p<0.05)$ lower (by 5\%) in children infected with CagA (+) strains than in children infected with CagA $(-)$ strains. Cellular density of infiltrates in patients infected with CagA (+) strains was significantly ( $p<0.05$ ) higher (by $26 \%$ ) compared with that of children infected with CagA (-) strains. Morphological and morphometric studies make it possible to determine quantitative and qualitative changes in the mucous membrane of the stomach in gastroduodenal pathology in children with Helicobacter pylori infection depending on the presence of cytotoxic strains, thereby increasing the quality and value of the diagnosis. Also, morphology enables one to predict the course of the disease and prevent complications, such as atrophy and dysplasia of the mucous membrane of the stomach.

\section{DISCUSSION}

In contrast to the results of other studies that indicate the prevalence of the average degree of colonisation by Helicobacter pylori in children with chronic gastroduodenitis ${ }^{(8,9)}$, we have shown that most patients had a low degree of colonisation - 88 (50.29\%); average colonisation was determined in $52(29.71 \%)$ and high in 35 (20\%) children. The analysis revealed that the occurrence of cytotoxic strains in children with chronic gastritis and gastroduodenitis depended on the degree of colonisation by Helicobacter pylori, with an average degree of probability $(p<0.05)$. CagA $(+)$ strains were more common in children with a high (51.92\%) than with a low degree of colonisation (35.23\%). Moreover, children with a high degree of colonisation were infected

\begin{tabular}{|c|c|c|}
\hline Indices & $\begin{array}{l}\text { Children with CagA (+) } \\
\text { Helicobacter pylori } \\
\text { strains, } n=38\end{array}$ & $\begin{array}{c}\text { Children with CagA (-) } \\
\text { Helicobacter pylori } \\
\text { strains, } n=37\end{array}$ \\
\hline $\begin{array}{c}\text { Total count } \\
\text { of inflammatory cells }\end{array}$ & $50.84 \pm 2.13^{*}$ & $25.03 \pm 0.71$ \\
\hline Plasmocyte count & $37.47 \pm 1.98^{*}$ & $18.81 \pm 0.50$ \\
\hline Lymphocyte count & $10.61 \pm 0.47^{*}$ & $5.35 \pm 0.33$ \\
\hline $\begin{array}{l}\text { Plasmocyte- } \\
\text { lymphocyte ratio }\end{array}$ & $3.72 \pm 0.22$ & $4.02 \pm 0.27$ \\
\hline $\begin{array}{l}\text { Relative volume } \\
\text { of epithelial cells [\%] }\end{array}$ & $0.0978 \pm 0.0038$ & $0.0962 \pm 0.0039$ \\
\hline $\begin{array}{l}\text { Relative volume } \\
\text { of capillaries [\%] }\end{array}$ & $0.00270 \pm 0.00048$ & $0.00267 \pm 0.00049$ \\
\hline $\begin{array}{l}\text { Capillary-epithelium } \\
\text { ratio }\end{array}$ & $0.0287 \pm 0.0038$ & $0.0281 \pm 0.0034$ \\
\hline $\begin{array}{l}\text { Height of epithelial } \\
\text { cells }[\mu \mathrm{m}]\end{array}$ & $15.42 \pm 0.25^{*}$ & $16.23 \pm 0.24$ \\
\hline $\begin{array}{l}\text { Relative volume } \\
\text { of affected epithelial } \\
\text { cells [\%] }\end{array}$ & $38.03 \pm 0.47^{*}$ & $30.73 \pm 0.37$ \\
\hline $\begin{array}{l}\text { Cell density } \\
\text { of infiltration }\end{array}$ & $15,861.37 \pm 119.77^{*}$ & $11,681.30 \pm 123.24$ \\
\hline
\end{tabular}

Tab. 1. Morphometric indices of the gastric mucosa in children with chronic gastroduodenal pathology associated with Helicobacter pylori

with CagA (+) strains of Helicobacter pylori in more cases (77.14\%), compared to children who had an average degree of colonisation $(51.92 \%)(p<0.05)$.

Morphological changes of the gastric mucosa in children with chronic gastritis and gastroduodenitis infected with CagA (+) Helicobacter pylori strains had a normal number of glands, slightly prolonged pits with focal thromboembolic epithelial metaplasia, plate fibrosis and expressed diffuse lymphoplasmic inflammatory infiltrates with the presence of segmental neutrophils and large lymphoid follicles in their own plate without replication centres. Also, in rare cases, dystrophic changes and focal desquamation of the glandular epithelium were observed. In 5 children (6.67\%) with chronic gastritis and gastroduodenitis infected with Helicobacter pylori CagA (+) strains, haemorrhages were observed, the presence of which may indirectly indicate damage and increased brittleness of the vascular walls. In this case, the morphological changes in the mucosa of children with CagA (-) strains of Helicobacter pylori were mainly accompanied by moderate lymphoplasmic infiltration of the plate with the lymphoid follicles with small centres of lymphocyte reproduction and focal thromboembolic metaplasia of the epithelium. There are reports, for example studies by Meanu, which demonstrate a 12-fold increase in the risk of developing intestinal metaplasia in adults who are infected with CagA (+) strains ${ }^{(10,11)}$. In Zak (2010), intestinal metaplasia was detected in $86.7 \%$ of adult patients ${ }^{(12)}$, while the development of intestinal metaplasia in children with chronic gastritis and gastroduodenitis in the course of infection with CagA (+) strains remains unknown ${ }^{(13)}$. 
Among all morphologically examined children with chronic gastritis and gastroduodenitis, 58 (77.33\%) patients $(77.33 \%)$ were diagnosed with small-cell metaplasia, which was more common in patients with CagA (+) strains of Helicobacter pylori (34 children, 58.62\%).

\section{CONCLUSIONS}

1. The morphological study has led to a conclusion that the presence of cytotoxic strains of Helicobacter pylori causes more significant changes in the gastric mucosa. In children with gastritis and gastroduodenitis infected with CagA (+) strains of Helicobacter pylori, active and deep chronic changes prevailed [21 $(28.00 \pm 5.18 \%)$ and 20 patients $(26.67 \pm 5.11 \%)$, respectively], whereas in the majority of children with CagA (-) strains, the inflammatory process was inactive and superficial [27 $(36.00 \pm 5.54 \%)$ and $23(30.67 \pm 5.32 \%)$, respectively].

2. In a morphometric study, it was found that in children with chronic gastritis and gastroduodenitis infected with CagA (+) strains of Helicobacter pylori, the total number of inflammatory cells was doubled, compared with the group of children with CagA (-) strains. In addition, children with cytotoxic strains of Helicobacter pylori presented a significant increase $(p<0.05)$ in the relative volume of epithelial cells and cell density of infiltrates (by $20 \%$ and $26 \%$ ) and in the number of plasmocytes and lymphocytes (a double increase) compared with patients infected with CagA (-) strains.

\section{Conflict of interest}

The authors do not report any financial or personal connections with other people or organisations that could adversely affect the content of the publication and claim the right to this publication.

\section{Acknowledgements}

The authors thank professor Dudnyk Veronika for support.

\section{References}

1. Kanivska LV, Kaushanskaya OV, Bedik NM et al.: [Helicobacter pylori as an actual problem of modern gastroenterology (review of literature)]. Young Scientist 2016; 2 (29): 156-160.

2. Stepanov YuM, Kovalenko OM, Oshmians'ka NYu: [Helicobacter pylori and morphofunctional characteristics of the gastric mucosa in patients with chronic reflux gastritis]. Modern Gastroenterology 2016; 6 (92): 24-29.

3. Lichkovskaya OL, Gnateyko OZ, Kech NR et al.: [Dynamics of the morphological state of the gastric mucosa in the early post-radiation period in children]. Scientific Journal ScienceRise 2016; 3/3 (20): 21-26.

4. Abaturov OYe, Zavgorodnya NYu: [Proliferative activity and antimicrobial resistance of the mucous membrane of the stomach in chronic HP-associated gastritis in children]. Modern Pediatrics 2012; 5 (45): 132-134.

5. Ryszczuk E, Roszko-Kirpsza I, Guzińska-Ustymowicz K et al.: EGFR and Bcl-2 in gastric mucosa of children infected with Helicobacter pylori. Postepy Hig Med Dosw (online) 2016; 70: 258-264.

6. Maciorkowska E, Kaczmarski M, Kemona A et al.: Comparative evaluation of gastric mucosa morphological changes in children and adults with positive IgG antibodies to Helicobacter pylori. Rocz AM Białyst 2003; 48: 100-104.

7. Aruin LI: [Morphological Diagnosis of Diseases of the Stomach and Intestines]. Triada X, Moscow 1998: 484.

8. Vartapetova EE, Salmova VS, Shcherbakov PL et al.: [Motorevacuation disorders of the upper parts of the digestive tract with Helicobacter pylori-associated diseases in children]. Paediatrics 2008; 87: 19-26.

9. Zamani A, Bahremand S, Zarrineghbal M et al.: [Results of endoscopic examination of the upper digestive tract in children with $H$. pylori infection and tenderness in the abdominal region]. Paediatrics 2008; 87: 26-31.

10. Makarenko EV: [Clinical significance of pathogenetic factors of Helicobacter pylori]. RZHGK 2005; (3): 22-27.

11. Chuang $\mathrm{CH}$, Yang HB, Sheu SM et al.: Helicobacter pylori with stronger intensity of CagA phosphorylation lead to an increased risk of gastric intestinal metaplasia and cancer. BMC Microbiol 2011; 11: 121.

12. Zak My: [Influence of toxigenic strains of $H$. pylori on morphological changes in the stomach mucus membrane in patients with chronic atrophic gastritis]. Succana Gastroenterology 2010; 5 (55): 37-42.

13. Maev IV, Govorun VM, Kucheryavyy YuA et al.: [Genetic polymorphism of interleukin-8 in patients with chronic gastritis and duodenal ulcer associated with Helicobacter pylori]. Clinical Perspectives of Gastroenterology, Hepatology 2008; (6): 3-8. 